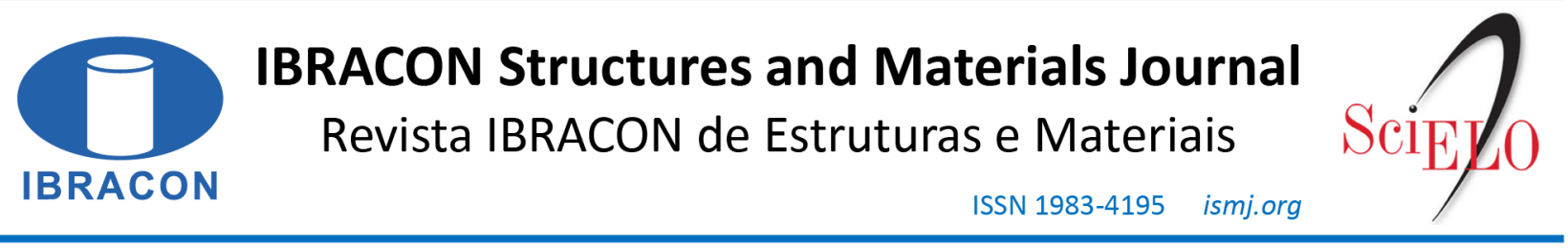

ORIGINAL ARTICLE

\title{
Eco-efficient steel slag concretes: an alternative to achieve circular economy
}

\section{Concretos ecoeficientes de escória de aciaria: uma alternativa para alcançar a econômica circular}

\author{
Laís Cristina Barbosa Costa $^{\mathrm{a}}$ (D) \\ Marcela Aguiar Nogueira ${ }^{a}$ (D) \\ Larissa Caroline Ferreira ${ }^{a}$ \\ Fernanda Pereira da Fonseca Elói ${ }^{\mathrm{a}}$ (D) \\ José Maria Franco de Carvalho ${ }^{\mathrm{b}}$ (D) \\ Ricardo André Fiorotti Peixoto ${ }^{a}$ (iD
}

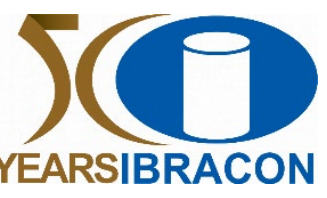

${ }^{a}$ Universidade Federal de Ouro Preto - UFOP, Laboratório de Materiais de Construção Civil, Ouro Preto, MG, Brasil

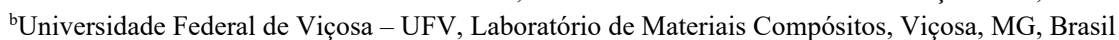

Received 01 April 2021

Accepted 19 July 2021

\begin{abstract}
Annually billions of tonnes of aggregates are extracted to apply in civil construction generating environmental impacts and energy consumption. So, based on circular economy principles applying residues as aggregates is a good solution to reduce the mining activity and to generate a more efficient destination for the residues. Thus, this research aims to evaluate the technical, economic, and environmental performance of concretes produced entirely with steel slag aggregates. The concretes were characterized through physical properties, as specific gravity, water absorption, compressive and tensile strength. Durability tests (expansibility) were also conducted. The authors analyzed the cost assessment and environmental impact of steel slag concrete production as well. The incorporation of steel slag increases the compressive and tensile strength of concrete, analyzed in different ages. Additionally, the steel slag does not present expansibility when confined in the concrete matrix. The entire replacement of natural aggregates for steel slag allowed to reduce in $31 \%$ the cement consumption, a decrease of $140 \mathrm{~kg} / \mathrm{m}^{3}$, for the same strength class. The environmental analysis showed that the incorporation of steel slag aggregates reduced the cement intensity of concrete and its impact. Regarding the cost assessment, the mixtures with steel slag presented a lower cost compared to the conventional one. These results indicate that steel slag aggregates could be used in a cleaner production of concrete, replacing natural aggregates with no injury. This research provides the feasibility of using steel slag aggregates in a cleaner and cheaper concrete production and contribute to the promotion of sustainable solutions for the construction sector through the circular economy principles.
\end{abstract}

Keywords: steel slag aggregate, compressive strength, cement intensity; circular economy.

Resumo: Anualmente bilhões de toneladas de agregados são extraídos para aplicação na construção civil, resultando em impactos ambientais e significativo consumo de energia. Assim, baseando-se nos princípios da economia circular, aplicar resíduos como agregados para construção civil é uma boa alternativa para reduzir a extração de recursos naturais e gerar uma destinação mais eficiente para os resíduos. Assim, essa pesquisa objetiva analisar o desempenho técnico, econômico e ambiental de concretos produzidos inteiramente com agregado de escória de aciaria. Os concretos foram caracterizados quanto suas propriedades físicas, como massa específica, absorção de água e resistência à compressão e tração. Ensaios de durabilidade (expansão) também foram realizados. Também foram analisados os custos do concreto de escória de aciaria e o seu impacto ambiental, através da intensidade de ligantes. Os concretos foram avaliados mecanicamente em diferentes idades, sendo observado que a incorporação de escória de aciaria aumenta a resistência à compressão e tração das matrizes. Além disso, em ensaios acelerados, a escória de aciaria não apresentou expansibilidade. A substituição total dos agregados naturais por escória de aciaria permitiu reduzir em $31 \%$ o consumo de concreto e cimento, o que representa um decréscimo de $140 \mathrm{~kg} / \mathrm{m}^{3}$ para a mesma classe de

Corresponding author: Laís Cristina Barbosa Costa. E-mail: lais.cristina.costa@gmail.com

Financial support: National Council for Scientific and Technological Development (CNPq, grant number 140896/2019-8).

Conflict of interest: Nothing to declare. 
resistência. Foi observado também que a incorporação de escória de aciaria reduz a intensidade de cimento das misturas e que essas possuem menor custo de produção comparado ao convencional. Esses resultados indicam que os agregados de escória de aciaria podem ser utilizados substituindo os agregados naturais sem causar danos. Este trabalho avalia a viabilidade de usar agregados de escória de aciaria na produção mais limpa de concretos, podendo contribuir para a promoção de soluções sustentáveis para o setor da construção através dos princípios da economia circular.

Palavras-chave: agregado de escória de aciaria, resistência à compressão, intensidade de ligantes, economia circular.

How to cite: L. C. B. Costa, M. A. Nogueira, L. C. Ferreira, F. P. F. Elói, J. M. F. Carvalho, and R. A. F. Peixoto, "Eco-efficient steel slag concretes: an alternative to achieve circular economy," Rev. IBRACON Estrut. Mater., vol. 15, no. 2, e15201, 2022, https://doi.org/10.1590/S198341952022000200001

\section{INTRODUCTION}

Gonçalves et al. [1] reported the economic feasibility of a steel slag processing plant to produce fine and coarse aggregates for civil construction. The viability of this processing plant is mostly related to the steel slag low cost of purchasing and the availability of the metallic material in steel slag (around $30 \mathrm{wt} . \%$ ) that can be sold. The utilization of steel slag as aggregate follows the circular economy practices aiding to reduce the environmental impact of all industry related in the processes, stimulating innovation, and optimizing the resource supplies. Due to the circular economy, the metallic material recovered returns to the productive chain, and the construction sector reduces its demand for raw materials. Also, historically the communities grow around industries, so the use of steel slag as aggregates could contribute for the local economy to strengthen, job creation and generation of new sustainable businesses.

Additionally, the incorporation of steel slag and other recycled aggregates assists in the reduction of the effects of natural aggregates extraction. The various types of coarse aggregates come from activities with significant water consumption, and affects the landscape and the existing biota [2]. The mining of river sand, used as fine aggregate, causes contamination of the water, increases turbidity, changes the geometry of the riverbed (including the flow) and damages flora and fauna [3].

Besides all these damages related to the mining of natural aggregates, it is important to highlight that the same river basin used for the sand extraction is demanded to supply the population with potable water, among other activities as agriculture and industry. Usually, the rivers cross cities and the sand extraction occurs near the urban centers, thus the consequences of this activity are close to the population with direct impact such as floods, visual and water pollution.

In Brazil, the Paraiba do Sul river has its sources in São Paulo passing through Minas Gerais and ending in Rio de Janeiro, states with a high rate of urbanization and participation in national GDP [4], [5]. This river basin provides water for 8.7 million people only in the metropolitan region of Rio de Janeiro [6], although the Paraiba do Sul river is the major reserve of sand in São Paulo state. Considering this environmental issue, the search for alternative solutions to replace the natural aggregates has raised, although some recycled aggregates possibilities are not easily available or drop with some concrete properties failing in the technical or economic analysis.

In 2017 the global production of steel generated around 1 billion tonnes of byproducts and residues, with $28 \%$ as steel slag [7]. The incorporation of steel slag as fine aggregate has potential to reduce the river sand extraction. Currently, around $28 \%$ of all existing mines in Brazil produce river sand [8].

The incorporation of steel slag as coarse and fine aggregate enhances the mechanical properties of concretes allowing increases of $20-40 \%$ in compressive strength compared to conventional concretes [9]-[15]. The higher hardness and better surface properties of steel slag particles promote this strength gain [16]-[20]. Some authors reported increases of about $40 \%$ in the compressive strength of conventional strength concretes $\left(\mathrm{f}_{\mathrm{ck}}<40 \mathrm{MPa}\right)$ produced with total replacement of the conventional coarse aggregate and partial substitution of the fine aggregate $(0-55 \%)$ with steel slag [9], [10], [21]-[23]. Additionally, many researchers evaluated the steel slag incorporation in precast elements such as structural masonry blocks [24], pavers [14], and its use as soil stabilizer [25]. Despite all available information, sitecast concretes produced with full replacement of natural aggregates by steel slag aggregates (coarse and fine) are still rare, but some spare results indicated the viability of eco-efficient concretes with steel slag aggregates [26].

However, the few existing papers related to steel slag concretes ignore environmental and economic parameters, focusing only on the technical feasibility. Answering the demand to incorporate circular economy concepts in the construction sector, the authors evaluate the technical, economic, and environmental performance of concretes produced with full replacement of natural aggregates by steel slag aggregates (coarse and fine fraction). These analyses had a fundamental relevance for the real applicability of this residue that contributes to cleaner production in the construction and steel industry. 


\section{METHODOLOGY}

\subsection{Materials}

For the production of the concretes, the chosen Portland cement was the Brazilian type CP IV - RS, called Portlandpozzolanic cement (PPC) due to partial substitution of clinker (15-50\%) by pozzolanic material [27]. This blended cement already has a reduced environmental impact, contributing to the production of a cleaner concrete. The specific gravity of the cement CP IV is $3.01 \mathrm{~g} / \mathrm{cm}^{3}$, and the chemical composition is indicated in Table 1 .

Table 1. Chemical composition of Portland cement CP IV

\begin{tabular}{cccccccccc}
\hline $\mathbf{S i O}_{2}$ & $\mathbf{A l}_{2} \mathbf{O}_{3}$ & $\mathbf{C a O}$ & $\mathbf{S O}_{3}$ & $\mathbf{M g O}$ & $\mathbf{K}_{2} \mathbf{O}$ & $\mathbf{F e}_{2} \mathbf{O}_{3}$ & $\mathbf{T i O}_{2}$ & $\mathbf{M n O}$ & $\mathbf{O t h e r}$ \\
\hline $19.2 \%$ & $5.5 \%$ & $64.5 \%$ & $4.3 \%$ & $0.8 \%$ & $0.9 \%$ & $3.6 \%$ & $0.3 \%$ & $0.4 \%$ & $0.5 \%$ \\
\hline
\end{tabular}

The conventional coarse and fine aggregates used in the production of the reference concretes were, respectively, gneiss gravel (4.8-12.5 mm) and quartz river sand $(0-4.8 \mathrm{~mm})$. A basic oxygen furnace steel industry located in João Monlevade provided the steel slag in particle sizes of $0-4.8 \mathrm{~mm}$ and $4.8-12.5 \mathrm{~mm}$, used as aggregates in the steel slag concrete.

This steel slag was subjected to a magnetic separation process to reduce its metallic iron content. To reduce the expansive oxides present in steel slag, Diniz et al. [25], Adegoloye et al. [28] and Pellegrino and Gaddo [21] verified the efficiency of the weathering process for periods superior to six months. The steel slag available for this research was subjected to four years of weathering through wet-dry cycles in a stockyard. Later in the experimental program, the stability of the steel slag applied in this research will be evaluated through macro and micro analysis. The appropriated treatment of steel slag is mandatory to allow its utilization without any future damage to the structures [29].

The particle size distribution of the reference and of steel slag aggregates (as received) differ. The particle size distribution of an aggregate is an important factor for the concrete properties. This affects the cement consumption, workability, mechanical performance, and many other properties [30], [31]. Therefore, this physical difference difficult the analysis of the technical, environmental and economic impact caused by the application of steel slag as aggregates in concrete. To physically adequate the aggregates, they had their particle size distributions equalized through sieving. The granulometry was chosen seeking for the minimum adjustment in both aggregates following the specifications of the standard NBR 7211 [32]. Figure 1 presents the particle size distribution used for the reference aggregate and for the steel slag aggregate (coarse and fine fraction).

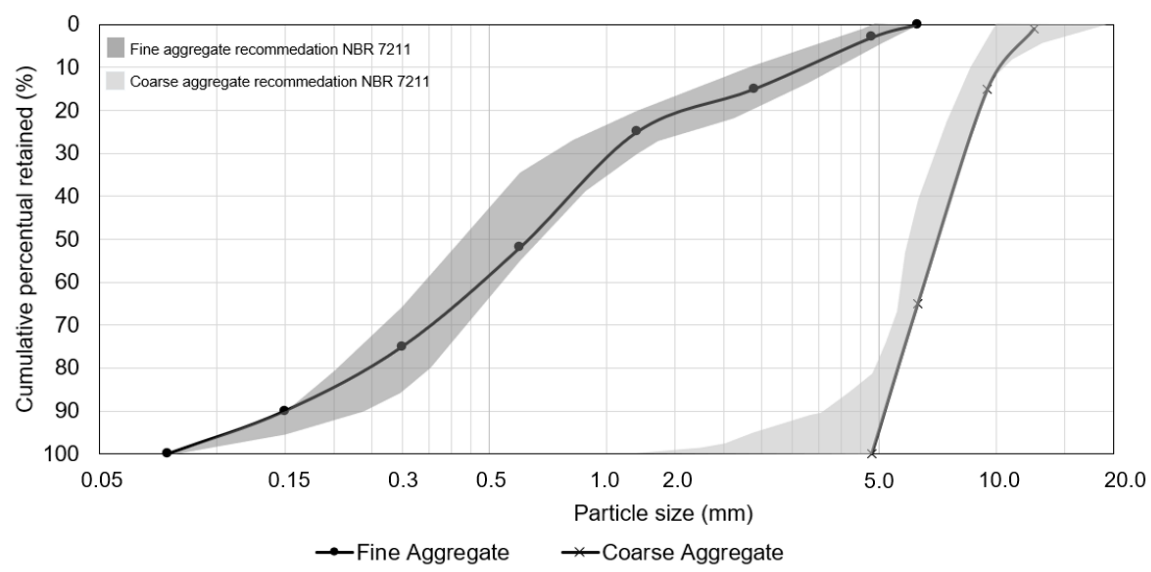

Figure 1. Particle size distribution for the coarse and fine aggregates

The complete physical characterization of the aggregates is shown in Table 2. The procedures were performed following the respective standard. The high specific gravity and bulk density of steel slag aggregates are due to their chemical composition, rich in metallic oxides as $\mathrm{CaO}, \mathrm{SiO}_{2}$ e $\mathrm{Fe}_{2} \mathrm{O}_{3}$ [14]. 
Table 2. Physical characterization of steel slag and reference aggregates

\begin{tabular}{|c|c|c|c|c|c|}
\hline & \multicolumn{2}{|c|}{ Fine Aggregates } & \multicolumn{2}{|c|}{ Coarse Aggregates } & \multirow{2}{*}{ Procedure Standard } \\
\hline & Steel slag & Reference & Steel slag & Reference & \\
\hline Specific gravity $\left(\mathrm{g} / \mathrm{cm}^{3}\right)$ & 3.74 & 2.68 & 3.58 & 2.61 & NBR 9776 [33]/ NBR NM 53 [34] \\
\hline Bulk density $\left(\mathrm{g} / \mathrm{cm}^{3}\right)$ & 2.22 & 1.63 & 1.77 & 1.44 & NBR NM $45[35]$ \\
\hline $\begin{array}{l}\text { Material finer than } 75 \mu \mathrm{m} \\
(\%)\end{array}$ & 8.06 & 6.26 & 1.93 & 0.81 & NBR NM 46 [36] \\
\hline Crushing strength (\%) & \multicolumn{2}{|c|}{-} & 89.41. & 82.90 & NBR 9938 [37] \\
\hline Shape Index & \multicolumn{2}{|c|}{-} & 1.47 & 1.81 & NBR 7809 [38] \\
\hline
\end{tabular}

Tap water from the public system of Ouro Preto (Brazil) was used in concrete production. A superplasticizer based in ether polycarboxylate was used to aid in the plasticity of the concretes and to reduce the water content.

\subsection{Microstructural analysis of the steel slag stability}

To verify the stability of the steel slag used in this experimental program, its chemical, mineralogical and thermal characterization was performed. For these procedures, a sample of steel slag was grounded in a ball mill ( $200 \mathrm{rpm}, 180$ minutes) and latter in a planetary ball mill ( $400 \mathrm{rpm}, 15$ minutes) until the material passed through the $45 \mu \mathrm{m}$ sieve. Additionally, this sample has a D50 below $10 \mu \mathrm{m}$ that ensures the accuracy of these analyses [39].

The chemical characterization proceeded through $\mathrm{x}$-ray fluorescence (PANalytical Epsilon3x) analyses. The mineralogical characterization was done by $\mathrm{x}$-ray diffraction (Bruker D2 Phaser) with the setup: CuK $\alpha$ radiation, $40 \mathrm{kV}$, $30 \mathrm{~mA}$, step size of $0.01^{\circ}$ and 1 second per step, in a $2 \theta$ range of $5-70^{\circ}$. The software PANalytical X'pert HighScore Plus V3.0 was used for mineral phase identification and quantification based in Rietveld refinement with ICDD PDF4+database. $10 \mathrm{wt} . \%$ of Fluorite (analytical grade, 99\% of purity) was used as an internal standard. The thermogravimetric and differential thermal analysis were evaluated simultaneously (TG/DTA - Shimadzu DTG-60H) using an atmosphere of inert $\mathrm{N} 2$ in a range from $25-1000^{\circ} \mathrm{C}$ with a heating rate of $10^{\circ} \mathrm{C} / \mathrm{min}$.

\subsection{Mix proportions and technical characterization of the concretes}

Physically identical concretes were designed by setting equally the design parameters. No specific strength classes were targeted, but instead, a small and a high cement content $\left(310 \mathrm{~kg} / \mathrm{m}^{3}\right.$ and $\left.450 \mathrm{~kg} / \mathrm{m}^{3}\right)$ were fixed, with the respective water/cement ratio of 0.62 and 0.44 . The mix design procedure selected was the Brazilian widely used methodology IPT/EPUSP [40], with a mortar content of 59\% set for all concretes. In the mix design, the specific gravity was considered to ensure the equivalent volume of aggregates in both conventional and steel slag concretes.

Concretes with similar workability allow the same applicability. Because of that, the concrete had a fixed slump. The slump test was realized according to the Brazilian standard NBR NM 67 [41]. The slump value adopted was $70 \pm 10 \mathrm{~mm}$ for the concretes with a cement consumption of $310 \mathrm{~kg} / \mathrm{m}^{3}$ and $90 \pm 10 \mathrm{~mm}$ for those with $450 \mathrm{~kg} / \mathrm{m}^{3}$ cement consumption.

Table 3 lists the concrete compositions and their respective slump test results. The code that identifies the produced concretes are REF for reference aggregates and BOFS for the basic oxygen furnace steel slag concretes.

Table 3. Mix Design of the steel slag and reference concretes produced

\begin{tabular}{ccccccc}
\hline Code & $\begin{array}{c}\text { Cement } \\
\left(\mathbf{k g} / \mathbf{m}^{\mathbf{3}}\right)\end{array}$ & $\begin{array}{c}\text { Fine Aggregate } \\
\left(\mathbf{k g} / \mathbf{m}^{\mathbf{3}}\right)\end{array}$ & $\begin{array}{c}\text { Coarse Aggregate } \\
\left(\mathbf{k g} / \mathbf{m}^{\mathbf{3}}\right)\end{array}$ & $\begin{array}{c}\text { Water } \\
\left(\mathbf{k g} / \mathbf{m}^{\mathbf{3}}\right)\end{array}$ & $\begin{array}{c}\text { Superplasticizer (\%) } \\
(\mathbf{m m})\end{array}$ \\
\hline REF-310 & 310 & 936.65 & 866.31 & 190.65 & 0.40 & 70 \\
\hline BOFS-310 & 310 & 1376.40 & 1171.86 & 190.65 & 0.25 & 70 \\
\hline REF-450 & 450 & 818.00 & 881.36 & 198.00 & 0.58 & 80 \\
\hline BOFS-450 & 450 & 1224.77 & 1163.83 & 198.00 & 0.35 & 100 \\
\hline
\end{tabular}

The superplasticizer dosage was empirical to achieve the required workability. Although, the saturation point of this chemical admixture combined with the cement type used was evaluated through a viscosity test proposed by 
Carvalho et al. [26], based on Aitcin [22]. The saturation point was $0.7 \%$. All the mixtures required a low superplasticizer content for the desired workability.

The order of material input in the mixing procedure was coarse aggregate, cement, and fine aggregate, each one with $1 / 3$ of the total mixing water. The superplasticizer was previously dissolved in the mixing water. The mixing time between material inputs was set in 30 seconds. An additional mixing time of 5 minutes was performed after the last material input. A 120-liter inclined-axis concrete mixer was used. The total mixing and sampling time was one hour.

For the physical characterization of the concretes, $\varnothing 50 \times 100 \mathrm{~mm}$ cylindrical specimens were cast and compacted in a flow table with 20 drops ( 1 drop/second). The specimens were maintained in a moisture chamber with a controlled environment $\left(95 \%\right.$ relative humidity and $\left.23^{\circ} \mathrm{C}\right)$ as required by the Brazilian standard NBR 9479 [42]. The tests were done after curing times of 28, 42 and 84 days.

Table 4 presents the concrete characterization program with the respective standards and the number of specimens evaluated. The maximum relative standard deviation of compressive strength was used to verify the reliability of the compressive strength results, in accordance with NBR 7215 [46].

Table 4. Characterization program of hardened concrete

\begin{tabular}{cccc}
\hline Procedure & Age & Repetitions & Standard \\
\hline Compressive Strength & 28,42 and 84 days & 4 specimens & NBR 5739 [43] \\
\hline Tensile strength by diametral compression & 28,42 and 84 days & 4 specimens & NBR 7222 [44] \\
\hline Specific gravity & 28 days & 3 specimens & NBR 9778 [45] \\
\hline Water absorption & 28 days & 3 specimens & NBR 9778 [45] \\
\hline Expansibility (Wet-Dry cycle) & 28 days & 4 specimens & - \\
\hline
\end{tabular}

The expansibility test to evaluate the durability of the steel slag aggregates in cement-based composites was developed through a wet-dry cycle experiment. The concrete specimens were subjected to 24 hour wet-dry cycles, comprising 24 hours in a wet chamber $\left(24 \pm 2{ }^{\circ} \mathrm{C}, 98 \% \mathrm{RH}\right.$., EQUILAM SSUM $)$ and 24 hour in local conditions $\left(22 \pm 2{ }^{\circ} \mathrm{C}, 35 \pm 5 \% \mathrm{RH}\right.$.), for a total period of 180 days. The dimensional variation was measured with a caliper ruler (precision $0.001 \mathrm{~mm}$ ), always at the same time. For the mechanical tests, a hydraulic press EMIC DL 2000 (load cell $200 \mathrm{kN}, 0.3 \mathrm{MPa} / \mathrm{s}$ ) was used, while the specific gravity and water absorption test were carried out with a SOLOTEST oven and wet bath.

\subsection{Economic evaluation}

The cost estimate of the concrete components considered the Brazilian National System of Costs Survey and Indexes of Construction (SINAPI) referring to February 2021 [47]. The unitary cost measured in volume was converted to mass and adjusted. This system collects information about the Brazilian construction sector since 1969, and it is recognized as a trustable source for the elaboration of construction estimates. For the steel slag aggregates, the value was obtained from a specialized processing plant in the metropolitan region of Belo Horizonte (Brazil). The economic viability of this plant was reported by Gonçalves et al. [1].

The concrete cost estimates were calculated for the mixture designed with the cost of the concrete components. The steel industry distribution in the Southeast Region of Brazil shows that most of the plants is located around the capitals or close to big cities. This Region is responsible for $52 \%$ of the Brazilian GDP [5] and has the country's biggest urbanization rate of $93 \%$ [4]. Also, the Southeast Region has around $42 \%$ of the Brazilian population. The metropolitan areas of the four states capitals concentrate $20 \%$ of the country's total population [48]. This proximity and the economic relevance of this region indicates that the steel slag generated could be used in the fabrication of concrete in the principal capitals of Brazil contributing to sustainable development in a circular economy model. Also, the last United Nations report included an adjustment in the human development index considering the carbon dioxide emission and material footprint [49]. This change reinforces the need to search for technological alternatives that contributes with circular economy principles, aiding to the stimulation of new sustainable businesses.

On a previous analysis Gonçalves [50] verified the economic feasibility of installation and operation of steel slag processing plant considering the impacts of stockyard and all previous steps related to the production of steel slag aggregate. Gonçalves [50] proposed that the processing plant should be a center of distribution of steel slag aggregated powered by steel slag provided for steel industries in the region. The maximum range of 150 kilometers between the processing plant and the steel industry allow the feasibility of the process. Figure 2 shows the map of the Southeast 
Region with the location of the steel industries (in gray), the state capitals (in black), and their respective radial distances.

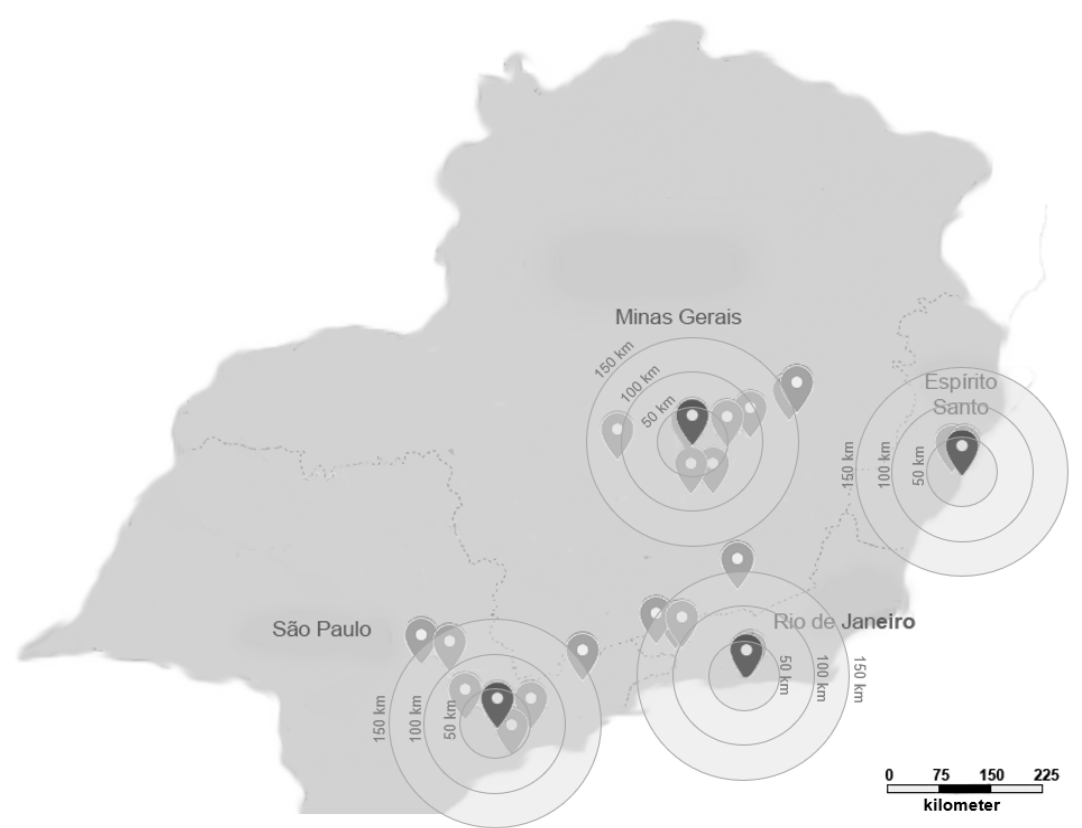

Figure 2. Map of Brazil's Southeast Region with the location of the steel industries and radial distances of the capital cities.

Figure 2 shows that all the steel industries located in the Brazilian southeast region are closer to the capitals under the range of $150 \mathrm{~km}$ required for the feasibility of steel slag processing plants [50]. The economic evaluation performed in this research considered the costs related after the production of steel slag aggregate, and the previous expenses are considered by Gonçalves [50]. This research assumes that the supply of construction material in the capitals, will have the same logistics both for steel slag aggregates and for the conventional aggregates. Because of that the expenses with transportation are not considered, as also indicated by the SINAPI.

\subsection{Characterization of the environmental performance}

An initial environmental performance of the concretes produced was evaluated through the cement intensity index proposed by Damineli et al. [51]. This coefficient is defined as the relation between the binder consumption (Portland cement, $\mathrm{kg} / \mathrm{m}^{3}$ ) of a concrete and its performance. The performance parameter chosen is the compressive strength.

All the concretes produced in this research have fixed cement consumption, so their $\mathrm{CO}_{2}$ emission related to cement production are equal. The steel slag aggregate environmental performance is indirectly analyzed through its contribution to the enhancement of compressive strength, which could enable the production of concretes with lower cement content, allowing the reductions in $\mathrm{CO}_{2}$ emission.

Additionally, the boundary conditions stablished for the economic evaluation are applied in the environmental analysis.

\section{RESULTS AND DISCUSSION}

\subsection{Microstructural analysis of the steel slag stability}

Table 5 shows the chemical and mineralogical composition of the steel slag. The BOF steel slag is basically composed by calcium, siliceous, iron and aluminum. Its chemical composition and phases are similar to the reported in literature [12], [52]-[55]. 
Table 5. Chemical and mineralogical composition of steel slag

\begin{tabular}{cccc}
\hline \multicolumn{2}{c}{ Chemical composition } & Mineralogical composition \\
\hline $\mathrm{CaO}$ & $36.2 \%$ & Brownmillerite $-\mathrm{Ca}_{2}(\mathrm{Al}, \mathrm{Fe})_{2} \mathrm{O}_{5}$ & $4.9 \%$ \\
\hline $\mathrm{SiO}_{2}$ & $13.4 \%$ & Calcite $-\mathrm{CaCO}_{3}$ & $4.8 \%$ \\
\hline $\mathrm{MgO}$ & $4.9 \%$ & Larnite $-\mathrm{Ca}_{2} \mathrm{SiO}_{4}$ & $6.3 \%$ \\
\hline $\mathrm{P}_{2} \mathrm{O}_{5}$ & $1.5 \%$ & Wustite $-\mathrm{FeO}$ & $4.4 \%$ \\
\hline $\mathrm{Al}_{2} \mathrm{O}_{3}$ & $3.6 \%$ & Periclase $-\mathrm{MgO}$ & $4.1 \%$ \\
\hline $\mathrm{MnO}_{\mathrm{Fe}} \mathrm{O}_{3}$ & $3.7 \%$ & Akermanite $-\mathrm{Ca}_{2} \mathrm{Mg}_{2}\left(\mathrm{Si}_{2} \mathrm{O}_{7}\right)$ & $2.3 \%$ \\
\hline $\mathrm{Outros}$ & $34.5 \%$ & Merwinite $-\mathrm{Ca}_{3} \mathrm{Mg}_{\left(\mathrm{SiO}_{4}\right)_{2}}$ & $1.0 \%$ \\
\hline & $2.2 \%$ & Amorphous & $72.2 \%$ \\
\hline
\end{tabular}

There is a general concern about the high content of lime $(\mathrm{CaO})$, periclase $(\mathrm{MgO})$ and wustite $(\mathrm{FeO})$ in steel slag, due to their expansiveness. Because of that, weathering processes are important to neutralize these expansive oxides, as indicated in literature [16]-[18]. The mineralogical phase identification of the steel slag (Table 5) shows low content of expansive oxides (lime, periclase, and wustite). Most of the calcium, iron, and magnesium are combined in other phases, this confirms the efficiency of weathering and the stability of steel slag. Also, it is noteworthy that these expansive oxides are confined in the inner of steel slag particles, the sample preparation allows the access to the expansive oxides.

Figure 3 presents the thermal analysis of the steel slag. In this sample, it is noticed three main loss ranges emphasized in the DTG curve. The first range indicates the release of adsorbed or free water. The second one relates to the dehydration of calcium hydroxide $\left(\mathrm{Ca}(\mathrm{OH})_{2}\right)$. The third one represents the decarbonation of the calcium carbonate $\left(\mathrm{CaCO}_{3}\right)$. The phases detected in the thermal analysis are also comprised in the DRX characterization (Table 5), as expected.

The content of the phases in the TG/DTA analysis are quantify through the mass loss related to the corresponding phase decomposition. It is known that $74.09 \mathrm{~g}$ of calcium hydroxide releases $18.01 \mathrm{~g}$ of water and $100.09 \mathrm{~g}$ of calcium carbonate releases $44.01 \mathrm{~g}$ of carbon dioxide during their decomposition. Thus, the content of $\mathrm{Ca}(\mathrm{OH})_{2}$ and $\mathrm{CaCO}_{3}$ are, respectively, $0.16 \%$ and $6.10 \%$, in good accordance with the DRX result (Table 5).

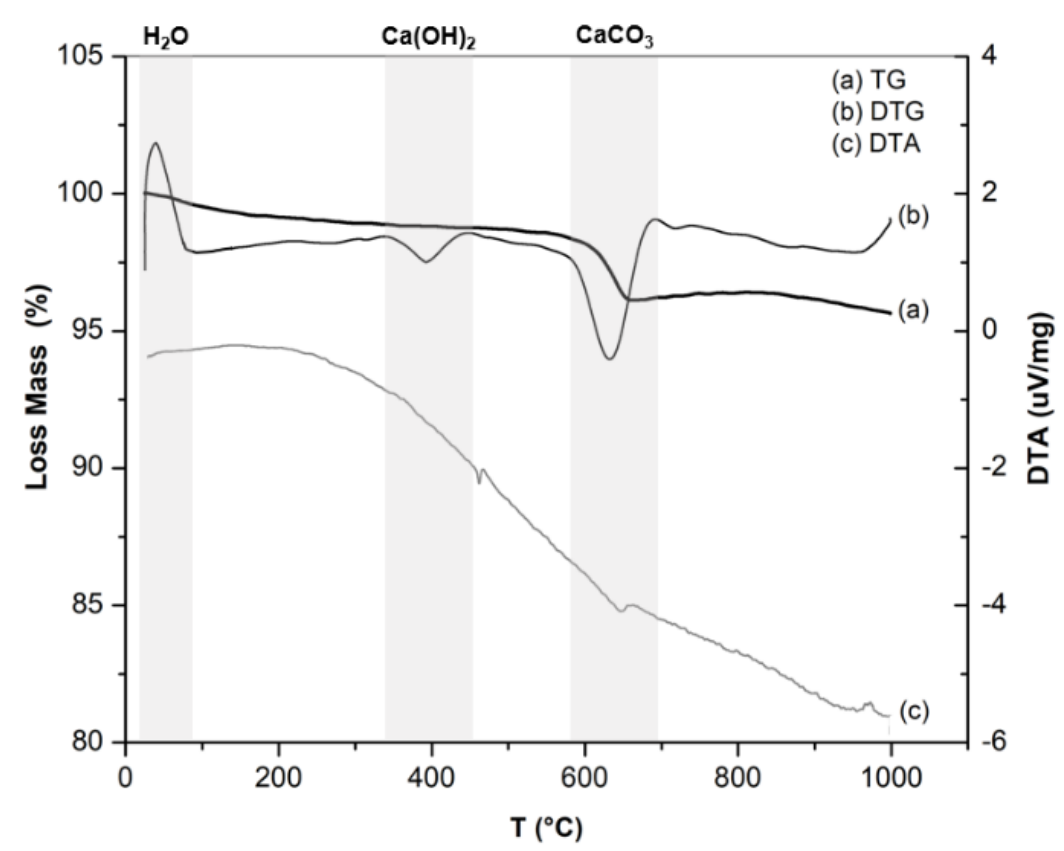

Figure 3. TG/DTA curves for the steel slag used

When generated, the steel slag has a high content of lime that, in contact with the water, forms calcium hydroxide. During the weathering process, the remaining lime and the calcium hydroxide are transformed into calcite, which could 
form a white layer outside the steel slag [56]. Thus, weathered steel slag usually has none or low content of calcium hydroxide [28], [57]. The TG/DTA result (Figure 3) and the mineralogical characterization (Table 5) present a low content of $\mathrm{Ca}(\mathrm{OH})_{2}$ explained for the longtime of weathering of the steel slag. The low content of calcium hydroxide and expansive oxides (Table 5) are indicatives of the stability of the steel slag and the efficiency of the weathering process.

Additionally, it is known that the reactivity (reaction rate) of a material is directly related with the specific surface [58], [59]. Only the steel slag in a powder fraction $(<75 \mu \mathrm{m})$, with high surface, has the reactivity needed to hydrate the expansive oxides implying in a dilution of these compounds in the matrix. According to Table 5, the sum of expansive oxides percentages $(\mathrm{CaO}, \mathrm{MgO}$, and $\mathrm{FeO})$ is $8.6 \%$. Artificial aggregates have a content $75-\mu \mathrm{m}$ finer material under 10\%, according to NBR 7211 [32]. Thus, the expansive oxides represent approximately $0.86 \mathrm{wt} . \%$ in all concrete mass, which allows to consider the steel slag as a stable aggregate.

\subsection{Technical characterization of the concretes}

Table 6 shows the results of the specific gravity of the produced concretes. As expected, the steel slag concretes presented a higher specific gravity. Neverless, the increase of $38 \%$ observed between the specific gravity of steel slag and reference aggregates become a difference of only $25 \%$ in the concrete specific gravity. The NBR 8953 [60] classifies the reference and steel slag concrete as normal-weight concretes $\left(2-2.8 \mathrm{~g} / \mathrm{cm}^{3}\right)$, which allows the use of the alternative concrete in typical structural applications, as columns and beans. Also, the increase in cement consumption does not affect the specific gravity of reference or steel slag concretes since the majority of the mixture volume is composed of aggregates.

Table 6. Specific gravity of the produced concretes

\begin{tabular}{cc}
\hline Concrete type & Specific gravity $\left(\mathbf{g} / \mathbf{c m}^{\mathbf{3}}\right)$ \\
\hline REF-310 & 2.14 \\
\hline BOFS-310 & 2.80 \\
\hline REF-450 & 2.22 \\
\hline BOFS-450 & 2.83 \\
\hline
\end{tabular}

The results of the water absorption test are shown in Figure 4. This property measures the permeable pores of the matrixes being indicative of their porosity. The full replacement of reference aggregates by steel slag led to a reduction in water absorption. The reduction in water absorption with the steel slag incorporation is probably related to the morphology of the aggregate. The reference coarse aggregates are elongated with a high shape index (1.81), while the steel slag is spherical with a shape index $18 \%$ smaller (1.48). In elongated aggregates the water tends to accumulate in their vicinity generating a more porous interfacial transition zone [31], [61].

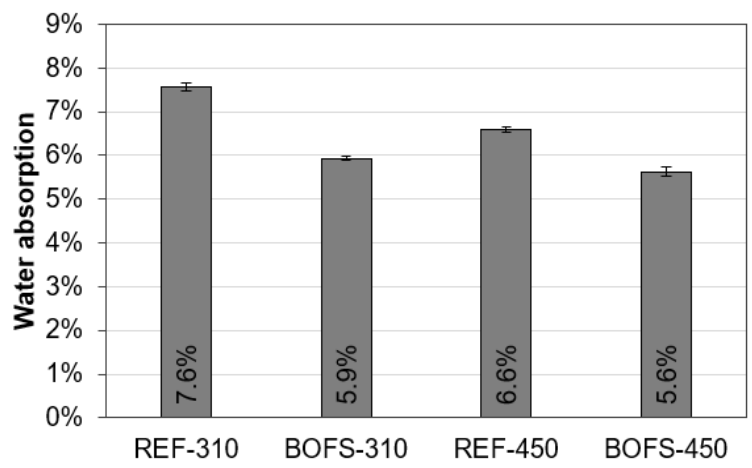

Figure 4. Water absorption of the concretes produced in the hardened state

Figure 5 presents the compressive strength of the concretes with ages of 28, 42 and 84 days. All the data presents a good correlation with the water absorption results (Figure 4). The incorporation of steel slag improved the mechanical performance of the concrete produced in all ages. This result is coherent with the literature, that reports enhancement in mechanical performance 
in concretes produced with steel slag aggregates [10], [21], [62], [63]. However, in this research, the mechanical performance of concrete was improved through total replacement of reference aggregates with steel slag, which can lead to a reduction in the extraction of aggregates by the construction sector and contributes with the recycling of this residue.

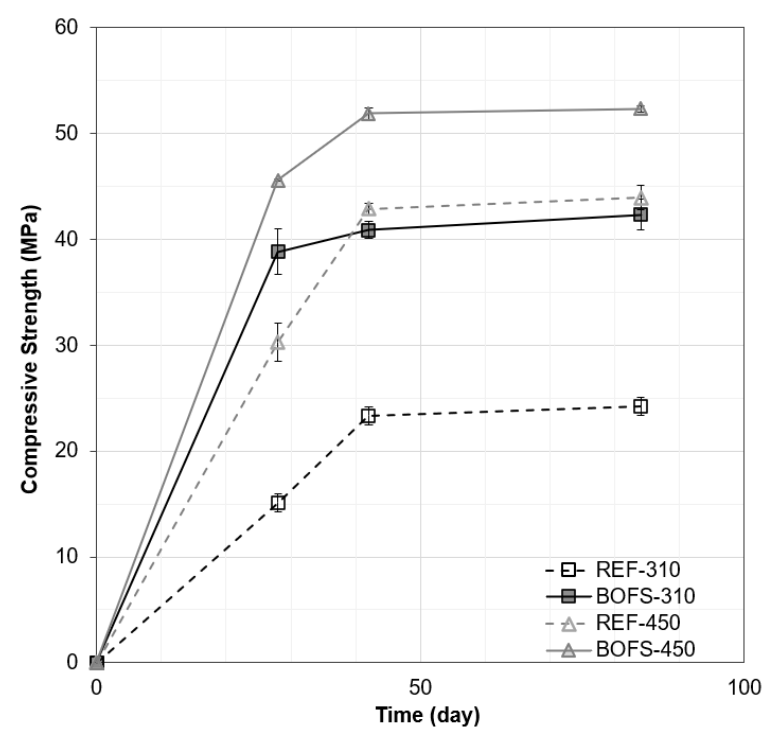

Figure 5. Compressive strength of the produced concretes

In general, the good performance of BOFS concretes is explained by the better crushing strength of the steel slag aggregate compared to reference one ( $7 \%$ higher), and the better shape index (closer to 1 - cubic morphology). The aggregates had a significant contribution in compressive strength, mostly in the concretes with compressive strength up to $40 \mathrm{MPa}$, where the rupture happens in the mortar [61]. Due to the equalization of concrete parameters (cement content, water/cement ratio, and mortar content), it was possible to evaluate the performance of the concretes in the same comparison basis.

At 28 days, BOFS-310 and BOFS-450 showed compressive strength about $156 \%$ and $50 \%$ higher than the relative reference concrete. In older ages (42- and 84 days), the steel slag incorporation improved the compressive strength of the concrete to a lesser extent. The strength enhancement was greater than the specific gravity increase $(\sim 30 \%)$ provided by incorporation of steel slag aggregates, offsetting any doubts about the higher structural weight by using steel slag.

These mechanical performance results indicate that it is possible to improve the mechanical performance of the matrixes using lower cement content, also reducing the hazardous activity of aggregate extraction through the steel slag incorporation. The lower cement content contributes to reducing the cement production that demands expensive milling and heating processes resulting in large $\mathrm{CO}_{2}$ emissions.

The enhancement in compressive strength in the steel slag concretes with higher cement content $\left(450 \mathrm{~kg} / \mathrm{m}^{3}\right)$ is smaller, because of the strength class of these concretes (higher than $40 \mathrm{MPa}$ ). In this case, the rupture happens in the coarse aggregate, because both concretes had the same mortar content and cement consumption. This explains the smaller difference in the results.

Another reason for the better mechanical performance of BOFS concrete is the significant content of material finer than $75 \mu \mathrm{m}$ in the fine steel slag aggregate. This finer material on both aggregates are in accordance with the normative requirements of NBR 7211 [32], although the BOFS aggregate has a content around 50\% higher than REF. The steel slag powder can refine the microstructure of the cement-based composite and has cementitious properties, as stated by the literature. Carvalho et al. [26] and Roslan et al. [64] reported that the full replacement of cement by steel slag powder increased the compressive strength of the specimens. Also, Wang and Yan [65] observed that the hydration of steel slag powder generated similar products of the cement hydration and some small reactivity of steel slag material finer than $75 \mu \mathrm{m}$ is reported in literature [18]. Additionally, the mineralogical composition of steel slag (Table 5) indicates a high amorphous phase content that could aid in this compressive strength.

The surface of the steel slag aggregate can also contribute to the improvement of compressive strength. Figure 6 shows images of the surface of steel slag and reference coarse aggregates obtained with a microscope. The rough surface of steel 
slag can increase the micro-adherence between aggregates and mortar. Additionally, this surface allows better hydration of the cement, and a smaller interfacial transition zone (ITZ) is formed, as reported by Brand and Roesler [66].

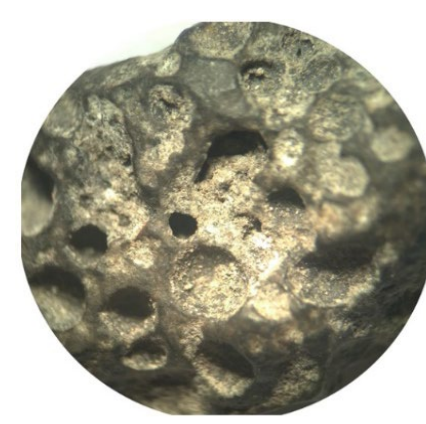

a)

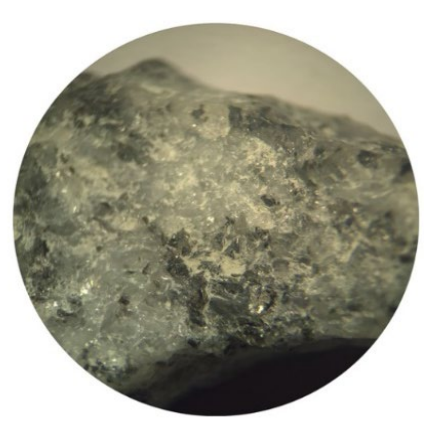

b)

Figure 6. Microscopy images of aggregates, $15 x$ magnification (a) steel slag (b) gneiss coarse aggregate

Overall, both concretes (REF and BOFS) present an increase in the compressive strength between 28 and 42 days. This occurs due to the use of a blended Portland cement with a high content of pozzolanic materials (up to $15 \%$ of clinker replacement). Supplementary cementitious materials, as pozzolanas, had a low rate of reaction with a higher effect in older ages [31], [67]. The increase in the compressive strength between 28 and 42 days is higher in the REF concrete. The BOFS concretes had a matrix more densely packed, due to the material finer than $75 \mu \mathrm{m}$, the shape, and the aggregate surface texture. On another hand, the reference aggregates are unfavorable for the densification of the matrix, thus the effect of pozzolanic material is emphasized. At the age of 84 days, the concrete strength is like the 42 days, indicating an almost constant behavior for both aggregates (BOFS and REF).

The tensile strength of the concretes produced at the age of 28, 42 and 84 days is indicated in Figure 7. In general, the tensile strength increases in the same manner as the compressive strength. The ITZ and the aggregate's shape and surface affect the tensile strength of concrete [68]. Then, the utilization of steel slag aggregates increases the tensile strength of concrete due to their higher strength, with a better shape index and with the contribution of possible cementitious action by the material finer than $75 \mu \mathrm{m}$ attached in the aggregates.

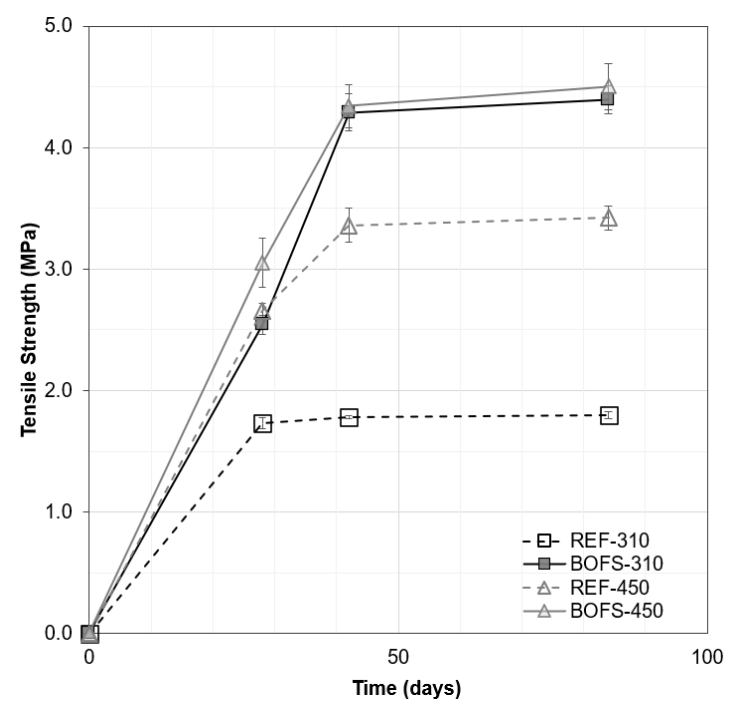

Figure 7. Tensile strength of the produced concretes

Figure 8 shows the dimensional variation of concrete specimens produced with steel slag and reference aggregates. The maximum length variation in the BOFS and REF sample occurs at 30 days being respectively $\sim 0.02 \%$ and $\sim 0.01 \%$. 
Both concretes showed similar behaviors. This small dimensional variation confirms the stability of steel slag aggregates provided for the weathering process; this result agrees with the findings of Silva et al. [14]. Also, this result reinforces the discussion about the mineralogical composition of steel slag (Table 2). Only the pulverulent material has the reactivity needed to hydrate the expansive oxides generating a dilution of these compounds.

The literature reports that the hydration of $\mathrm{MgO}, \mathrm{CaO}$, and $\mathrm{FeO}$ generates volumetric expansions of approximately $119.5 \%, 99.4 \%$, and $109.6 \%$, respectively (Weast, 1987). However, the BOFS sample maintained intact during the test time. This implies that the confinement tension of cement paste is enough to avoid cracks and efflorescence in the cementitious matrixes containing low contents of expansive oxides.

The enhancement in the compressive strength of BOFS concrete at older ages (Figure 5) is another indication of the potential applicability of steel slag aggregates to produce cleaner concretes, where its use does not imply reduction in the concrete performance.

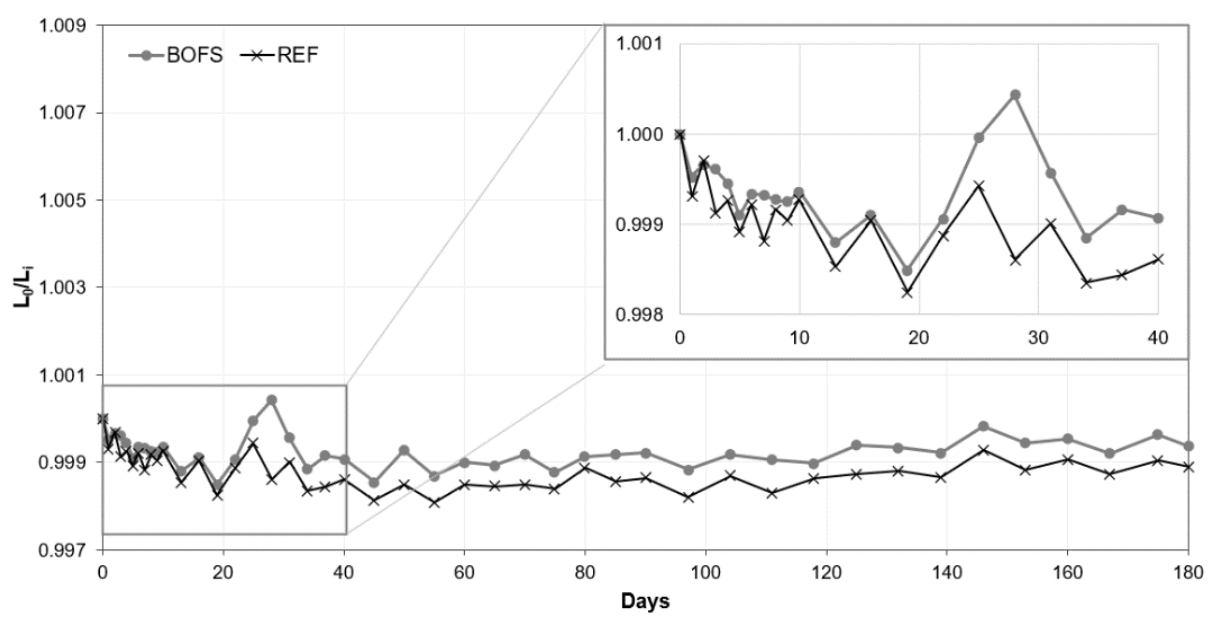

Figure 8. Expansibility of concrete specimens

\subsection{Economic evaluation}

Table 7 shows the average cost of the concrete insume. The steel slag cost is equivalent to $6 \%$ of the reference coarse aggregate cost. Despite the demand of processing the steel slag, this aggregate still presenting a competitive price. This is due to the high efficiency in the recuperation of metallic material in the processing plant, the value spent in the purchase and processing of steel slag is equal to $24 \%$ of the amount obtained by the sale of the metallic material [1]. Additionally, the reuse of the metallic material aids to reduce the supply of raw materials and the waste generation in this processing plant. Incorporating steel slag aggregates in construction sector also has other indirect benefit as creating jobs, boosting the economy grow of local communities, besides other social aspects.

Table 7. Current prices of the concrete inputs in Brazil (reference year: 2020)

\begin{tabular}{cc}
\hline Material & Average price/unit \\
\hline Cement CP IV RS & USD 4.90/ 50 kg bag \\
\hline Medium River sand & USD 12.56/tonne \\
\hline Gneiss gravel & USD 16.83/tonne \\
\hline Steel slag aggregate & USD 1.00/tonne \\
\hline
\end{tabular}

The cost of the production of $1 \mathrm{~m}^{3}$ of concrete is indicated in Table 8 . The benefit of using steel slag aggregates is clearer in the concretes with smaller cement consumption. These concretes have a higher volume of aggregates that generates a higher reduction in the cost. The production of BOFS-310 concrete is $36 \%$ more economical than REF310 ; for the BOFS-450 the cost decrease is $27 \%$ compared to REF- 450 . Considering the already reported economic feasibility for the installation of steel slag processing plants [1], the reduced cost for the fabrication of the steel slag concrete is another indicative of the feasibility of using the steel slag aggregates. 
Also, for the same cement consumption the concretes produced with steel slag have a higher compressive strength (Figure 5), so the cost per MPa of steel slag concretes is significantly smaller than the reference concretes. For a real situation, with a specific compressive strength class, the cost saving using steel slag aggregate is higher, since it will demand a smaller cement consumption to produce some concrete with the same compressive strength.

Table 8. Estimate cost of the concretes produced in this work

\begin{tabular}{ccc}
\hline Concrete type & Average price for 1 cubic meter produced & Cost per MPa \\
\hline REF-310 & $48.62 \mathrm{USD}$ & $2.08 \mathrm{USD} / \mathrm{m}^{3}$ \\
\hline BOFS-310 & $31.52 \mathrm{USD}$ & $0.77 \mathrm{USD} / \mathrm{m}^{3}$ \\
\hline REF-450 & $61.58 \mathrm{USD}$ & $1.44 \mathrm{USD} / \mathrm{m}^{3}$ \\
\hline BOFS-450 & $45.16 \mathrm{USD}$ & $0.87 \mathrm{USD} / \mathrm{m}^{3}$ \\
\hline
\end{tabular}

\subsection{Environmental performance}

The results of the cement intensity of the produced concretes are listed in Table 9. Steel slag concretes had a lower cement intensity than the reference one. This result was expected since the cement consumption was fixed and the compressive strength of these concretes was higher. Additionally, the research used a blended cement with a low content of clinker (50-85 wt.\%). It is known that it is possible to save $830 \mathrm{~kg}$ of $\mathrm{CO}_{2}$ for each tonne of clinker displaced [69]. Thus, despite all the results the concretes produced already have a higher eco-efficiency.

Table 9. Cement intensity of steel slag and reference concretes produced

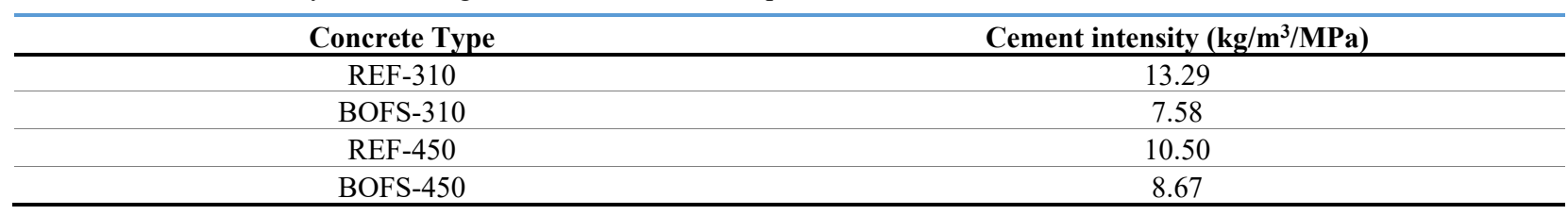

Daminieli et al. [51] analyzed several concrete data from around the world and observed that, in general, the cement intensity is in a range of $5-20 \mathrm{~kg} / \mathrm{m}^{3} / \mathrm{MPa}$. The concretes produced in this work are among this limit. In general, the lowest binder intensities reported by Daminieli et al. [51], around $4 \mathrm{~kg} / \mathrm{m}^{3} / \mathrm{MPa}$, is related to high strength concretes (superior to $200 \mathrm{MPa}$ ) with the incorporation of silica fume, high packing densities, and very low water/cement ratio. These are very specialized concretes that have little applicability. Besides, the steel slag concretes produced are in the regular range [51], the complete replacement of the conventional aggregates to steel slag aggregates generated a reduction in cement intensity of $43 \%$ and $17 \%$ for the concretes with $310 \mathrm{~kg} / \mathrm{m}^{3}$ and $450 \mathrm{~kg} / \mathrm{m}^{3}$, respectively.

Although the compressive strength class of BOFS-310 is equivalent to REF-450, this indicates that to produce a steel slag concrete with a compressive strength like the REF-310 is required a small amount of cement. Then, it is proposed a correction factor in the cement intensity (Cbi). Equation 1 indicates the calculation of the Cbi. The application of the Cbi in the cement intensity obtained for BOFS-310 indicates a new value of $5.22 \mathrm{~kg} / \mathrm{m}^{3} / \mathrm{MPa}$, closer to the inferior limit of Daminieli et al. [51].

$$
f_{c 310}^{B O F S}=f_{c 450}^{R E F} ; C b i=\frac{310}{450}=0.69
$$

Carvalho et al. [52] studied concretes produced with steel slag aggregate and a fine fraction of steel slag in replacement of cement finding a cement intensity around $3.5 \mathrm{~kg} / \mathrm{m}^{3} / \mathrm{MPa}$. This low cement intensity is attributed to the fine fraction of steel slag that requires grinding in a ball mill with at least $200 \mathrm{rpm}$ for more than 180 minutes. Then, a cement intensity around $8 \mathrm{~kg} / \mathrm{m}^{3} / \mathrm{MPa}$ of BOFS concretes with less or no processing is an excellent result that could represent a greater environmental performance than a concrete with a cement intensity of $3 \mathrm{~kg} / \mathrm{m}^{3} / \mathrm{MPa}$.

Although the cement intensity only measures the environmental effect of cement production, all concrete produced in this research has the same cement consumption. Considering this, an initial environmental performance related to the aggregate replacement could be indirectly considered. In general, the use of steel slag in this research represents a significant reduction in the $\mathrm{CO}_{2}$ emission due to a thereduction in cement consumption without using expensive 
gridding procedures or materials. The total replacement of reference aggregates to steel slag represents an effective and easy way to reduce the environmental impact of the construction sector, contributing to the production of cleaner concretes. Probably the combination of steel slag aggregates with mineral admixtures producing high strength concretes can generates a more significant reduction in the cement intensity.

\subsection{Consideration about feasibility}

Figure 9 summarizes the main data obtained in this research. For the elaboration of the radar chart, all the results were normalized to a scale of 1 to 5 . The mixture design with the best performance in the parameter received grade 5, and the others were proportionally calculated on this scale. In this way, the most external curve represents the concrete mixture that encompasses the best technical characteristics, the small cost, and the lower environmental impact. The steel slag concretes are closer to the outside limit, although the main difference is the cost. Stands out that the reduction in the cost of concrete production is particularly important in Brazil, which has a housing deficit of 6 million units, mostly (84\%) for low-income families [70]. Because of that, the BOFS-310 is established as the best mixture design. Also, the BOFS-310 had the smallest cement intensity $\left(7.58 \mathrm{~kg} / \mathrm{m}^{3} / \mathrm{MPa}\right)$ showing its eco-efficiency. Anyway, steel slag aggregate revealed a solution to a cleaner production of concrete in construction sector, contributing to the reduction of natural aggregates mining and the consequent effects in society. The reference concretes were hatched to simplify the analysis.

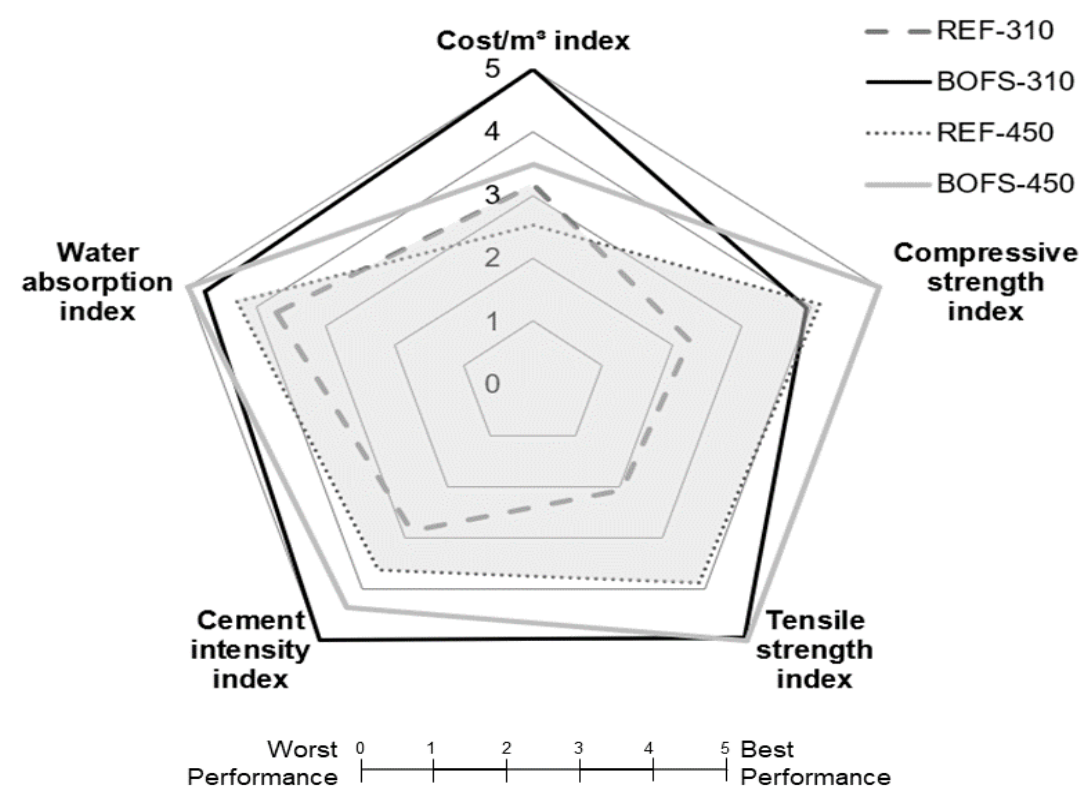

Figure 9. Radar chart of the technical, economic and environmental performance analysis of the concretes. Parameters are normalized, where 5 is the best performance and 0 the worst one.

\section{CONCLUSION}

This work evaluates a cleaner production solution for the steel slag residue which contributes to the promotion of new strategies of circular economy. The steel slag (BOFS fine and coarse fraction) entirely replaced the conventional aggregates in the production of eco-efficient concretes. Besides the experimental program to evaluate the durability, mechanical and physical properties of the steel slag concrete, this work evaluated the economic and environmental impact of this material. The main findings of this work are:

- The novel data collected in the microstructural analysis of the steel slag stability through different techniques (FRX, DRX and TG/DTA) indicated the weathered stage of this residue. Additionally, the expansive oxides are accessible 
and reactive only in a powder condition $(<75 \mu \mathrm{m})$, which implies in a significant dilution of this compound in the matrix and its hazardous potential.

- The BOFS aggregates improve the compressive and tensile strength of the concrete due to its hardness and morphology. Additionally, the material finer than $75 \mu \mathrm{m}$ presented in the steel slag aggregate contributes to the densification of the matrix acting as a cementitious material. These results associated with the broad explanation about the steel slag microstructure is important to better understand the various gaps remaining related to the expansiveness of steel slag and the efficiency of weathering processes.

- The BOFS concrete has a similar compressive strength compared to reference one with a reduction of $140 \mathrm{~kg} / \mathrm{m}^{3}$ $(\sim 31 \%)$ in the cement content. This enhancement in the mechanical performance of concrete is the main responsible for the lower environmental impact that results in a more eco-efficient product.

- For the cost estimation, the concretes produced with steel slag aggregates presented a cost $27-36 \%$ lower than the reference ones. This results in the production of a cement-based composite more accessible for low-income constructions.

- The cost and environmental analysis of steel slag aggregates are new in the literature and indicated that this material is a preferable alternative to the natural aggregates.

The physical properties results, and expansibility test conducted indicated that steel slag aggregates could be used in structural elements. This aggregate allows the production of concrete with lower content of Portland cement implying in a decrease of $\mathrm{CO}_{2}$ emission by the construction industry. Additionally, the steel slag aggregate has a lower production cost compared to the extraction of natural aggregates reducing the total cost of concrete production.

Brazil has a housing deficit of more than 6 million of dwellings, mostly of low-income families [70], so the steel slag aggregates could aid in the housing problem, since the BOFS concrete is more resistant, durable and have smaller cost than regular concrete. It is important to point out that historically many communities are born around industries, so the use of steel slag aggregate in construction sector aids strengthening the economy through job creation and generation of sustainable businesses.

Besides all the contributions listed above, the use of steel slag aggregates also comprises an economic opportunity for new cleaner businesses that could provide environmental and social benefits. The results presented in this work adds in a definition of new strategies for circular economy. It is mandatory to update the productive system and seek for ways to expand the economy in a sustainable way. The use of steel slag as aggregate is an alternative for the resource scarcity contributing for reduction in the demand for natural resources of the construction sector and steel industry.

\section{ACKNOWLEDGMENTS}

We gratefully acknowledge the Ministry of Science, Technology, Innovation and Communications, the National Council for Scientific and Technological Development (CNPq) and the agencies CAPES and FAPEMIG for providing financial support. We are also grateful for the infrastructure and collaboration of the Research Group on Solid Waste RECICLOS - CNPq.

\section{REFERENCES}

[1] D. Gonçalves, W. Fontes, J. Mendes, G. Silva, and R. Peixoto, "Evaluation of the economic feasibility of a processing plant for steelmaking slag," Waste Manag. Res., vol. 34, no. 2, pp. 107-112, 2016.

[2] M. Alexander and S. Mindess, Aggregates in Concrete. New York: CRC Press, 2005.

[3] D. Padmalal, K. Maya, S. Sreebha, and R. Sreeja, "Environmental effects of river sand mining: a case from the river catchments of Vembanad lake, Southwest coast of India," Environmental Geology, vol. 54, no. 4, pp. 879-889, 2008.

[4] Instituto Brasileiro de Geografia e Estatística, Censo Demográfico. Rio de Janeiro: IBGE, 2010.

[5] Instituto Brasileiro de Geografia e Estatística, Contas Regionais do Brasil. Rio de Janeiro: IBGE, 2016.

[6] C. Carvalho, Extração de Areia Vai Aumentar no Paraíba do Sul. Brasília: Agência Nacional de Águas, 2019.

[7] Instituto Aço Brasil, Relatório de Sustentabilidade 2016-2017. Rio de Janeiro: IABR, 2018.

[8] Brasil. Ministério de Minas e Energia. Departamento Nacional de Produção Mineral, Universo da Mineração Brasileira 2006. Brasilia: DNPM, 2007.

[9] S. Monosi, M. Ruello, and D. Sani, "Electric arc furnace slag as natural aggregate replacement in concrete production," Cement Concr. Compos., vol. 66, pp. 66-72, 2016. 
[10] J. San-José, I. Vegas, I. Arribas, and I. Marcos, "The performance of steel-making slag concretes in the hardened state," Mater. Des., vol. 60, pp. 612-619, 2014.

[11] H. Beshr, A. A. Almusallam, and M. Maslehuddin, "Effect of coarse aggregate quality on the mechanical properties of high strength concrete," Constr. Build. Mater., vol. 17, no. 2, pp. 97-103, 2003.

[12] I. Papayianni and E. Anastasiou, "Production of high-strength concrete using high volume of industrial by-products," Constr. Build. Mater., vol. 24, no. 8, pp. 1412-1417, 2010.

[13] C. Pellegrino, P. Cavagnis, F. Faleschini, and K. Brunelli, "Properties of concretes with Black/Oxidizing Electric Arc Furnace slag aggregate," Cement Concr. Compos., vol. 37, pp. 232-240, 2013.

[14] M. Silva, B. Souza, J. Mendes, G. Brigolini, S. Silva, and R. Peixoto, "Feasibility study of steel slag aggregates in precast concrete pavers," ACI Mater. J., vol. 113, no. 4, pp. 439-446, 2016.

[15] H. Andrade, J. Carvalho, L. Costa, F. Elói, K. Silva, and R. Peixoto, "Mechanical performance and resistance to carbonation of steel slag reinforced concrete," Constr. Build. Mater., vol. 298, pp. 123910, 2021.

[16] I. Grubeša, I. Barisic, A. Fucic, and S. Bansode, Characteristics and Uses of Steel Slag in Building Construction, 1st ed. Cambridge: Woodhead Publ., 2016.

[17] Y. Jiang, T. Ling, C. Shi, and S. Pan, "Characteristics of steel slags and their use in cement and concrete: a review," Resour. Conserv. Recycling, vol. 136, pp. 187-197, 2018.

[18] A. Martins et al., "Steel slags in cement-based composites: an ultimate review on characterization, applications and performance," Constr. Build. Mater., vol. 291, pp. 123265, 2021.

[19] G. Wang, The Utilization of Slag in Civil Infrastructure Construction. Cambridge: Woodhead Publ., 2016.

[20] I. Z. Yildirim and M. Prezzi, "Chemical, mineralogical, and morphological properties of steel slag," Adv. Civ. Eng., vol. 2011, pp. 13, 2011.

[21] C. Pellegrino and V. Gaddo, "Mechanical and durability characteristics of concrete containing EAF slag as aggregates," Cement Concr. Compos., vol. 31, no. 9, pp. 663-671, 2009.

[22] P.-C. Aïtcin, "Cements of yesterday and today concrete of tomorrow," Cement Concr. Res., vol. 29, no. 9, pp. 1349-1359, Nov 2000.

[23] Y. Guo, J. Xie, J. Zhao, and K. Zuo, "Utilization of unprocessed steel slag as fine aggregate in normal- and high-strength concrete," Constr. Build. Mater., vol. 204, pp. 41-49, 2019.

[24] R. Januzzi, L. Costa, R. Peixoto, and A. Cury, "Study of the mechanical behavior of prisms composed by two blocks produced with eletrical steel slag for structural masonry," Mason. Int., vol. 31, pp. 80-87, 2019.

[25] D. Diniz, J. Carvalho, J. Mendes and R. Peixoto, "Blast oxygen furnace slag as chemical soil stabilizer for use in roads," J. Mater. Civ. Eng., vol. 29, no. 9, pp. 1-7.

[26] J. Carvalho, T. Melo, W. Fontes, J. Batista, G. Brigolini, and R. Peixoto, "More eco-efficient concrete: an approach on optimization and use of waste-based supplementary cementing materials," Constr. Build. Mater., vol. 206, pp. 397-409, 2019.

[27] Associação Brasileira de Normas Técnicas,, Cimento Portland-Requisitos, NBR 16665, 2018.

[28] G. Adegoloye, A.-L. Beaucour, S. Ortola, and A. Noumowe, "Mineralogical composition of EAF slag and stabilised AOD slag aggregates and dimensional stability of slag aggregate concretes," Constr. Build. Mater., vol. 115, pp. 171-178, 2016.

[29] J. Guo, Y. Bao, and M. Wang, "Steel slag in China: treatment, recycling, and management," Waste Manag., vol. 78, pp. 318-330, 2018.

[30] J. F. Young, S. Mindess, R. J. Gray, and A. Bentur, The Science and Technology of Civil Engineering Materials. New Jersey: Prentice Hall, 1998.

[31] P. K. Mehta and P. J. M. Monteiro, Concrete: Microstrucuture, Properties and Materials. New York: McGraw-Hill, 2006.

[32] Associação Brasileira de Normas Técnicas, Agregado para Concreto - Especificação, ABNT NBR 7211, 2009.

[33] Associação Brasileira de Normas Técnicas, Aggregate - Determination of Fine Aggregate Specific Gravity by Chapman Vessel Method of Test, ABNT NBR 9776, 1986.

[34] Associação Brasileira de Normas Técnicas, Agregado Graúdo - Determinação de Massa Específica, Massa Específica Aparente e Absorção de Água, ABNT NBR NM 53, 2009.

[35] Associação Brasileira de Normas Técnicas, Agregados - Determinação da Massa Unitária e do Volume de Vazios, ABNT NBR NM 45, 2006.

[36] Associação Brasileira de Normas Técnicas, Agregados - Determinação do Material Fino que Passa Através da Peneira 75 Micrometro, por Lavagem, ABNT NBR NM 46, 2003.

[37] Associação Brasileira de Normas Técnicas, Agregados - Determinação da Resistência ao Esmagamento de Agregados Graúdos Método de Ensaio, ABNT NBR 9938, 2013.

[38] Associação Brasileira de Normas Técnicas, Agregado Graúdo - Determinação do Índice de Forma pelo Método do Paquímetro Método de Ensaio, ABNT NBR 7809, 2019. 
[39] K. Scrivener, R. Snellings, and B. Lothenbach, A Practical Guide to Microstructural Analysis of Cementitious Materials. Boca Raton: CRC Press, 2016.

[40] P. Helene and P. Terzian, Manual de Dosagem e Controle do Concreto, 1a ed. São Paulo: Pini, 1992.

[41] Associação Brasileira de Normas Técnicas, Concreto - Determinação da Consistência pelo Abatimento do Tronco de Cone, ABNT NBR NM 67, 1998.

[42] Associação Brasileira de Normas Técnicas, Argamassa e Concreto - Câmaras Úmidas e Tanques para Cura de Corpos-de-Prova, ABNT NBR 9479, 2006.

[43] Associação Brasileira de Normas Técnicas, Concreto - Ensaio de Compressão de Corpos de Prova Cilindricos, ABNT NBR 5739, 2018.

[44] Associação Brasileira de Normas Técnicas, Concreto e Argamassa-Determinação da Resistência à Tração por Compressão Diametral de Corpos de Prova Cilindricos, ABNT NBR 7222, 2011.

[45] Associação Brasileira de Normas Técnicas, Argamassa e Concreto Endurecidos - Determinação da Absorção de Água, Índice de Vazios e Massa Especifica, ABNT NBR 9778, 2005.

[46] Associação Brasileira de Normas Técnicas, Cimento Portland-Determinação da Resistência à Compressão, ABNT NBR 7215, 2014.

[47] Sistema Nacional de Pesquisa de Custos e Índices da Construção Civil, Relatório de Insumos e Composições- FEV/2021: Minas Gerais, Rio de Janeiro e São Paulo. Rio de Janeiro: SINAPI, 2021.

[48] Instituto Brasileiro de Geografia e Estatística, Estimativas da População dos Municípios com Data de $1^{\circ}$ de Julho de 2018 . Rio de Janeiro: IBGE, 2018.

[49] United Nations Development Programme, Human Development Report 2020 - The Next Frontier: Human Development and the Anthropocene. New York: UNDP, 2020.

[50] D. R. R. Gonçalves, “Análise da viabilidade econômica via simulação de Monte Carlo para utilização da escória de aciaria como agregado na fabricação de pré-fabricados para a construção civil - ecoblocos,” M.S. thesis, Univ. Fed. Ouro Preto, Ouro Preto, 2015.

[51] B. Damineli, F. Kemeid, P. Aguiar, and V. John, "Measuring the eco-efficiency of cement use," Cement Concr. Compos., vol. 32, no. 8, pp. 555-562, 2010.

[52] J. Carvalho, W. Fontes, C. Azevedo, G. Brigolini, and R. Peixoto, "Enhancing the eco-efficiency of concrete using engineered recycled mineral admixtures and recycled aggregates," J. Clean. Prod., vol. 257, pp. 120530, 2020.

[53] L. Franco, J. Mendes, L. Costa, R. Pira, and R. Peixoto, "Design and thermal evaluation of a social housing model conceived with bioclimatic principles and recycled aggregates," Sustain. Cities Soc., vol. 51, pp. 101725, 2019.

[54] A. Santamaria, A. Orbe, J. San José, and J. González, "A study on the durability of structural concrete incorporating electric steelmaking slags," Constr. Build. Mater., vol. 161, pp. 94-111, 2018.

[55] C. Li, Z. Chen, S. Wu, B. Li, J. Xie, and Y. Xiao, "Effects of steel slag fillers on the rheological properties of asphalt mastic," Constr. Build. Mater., vol. 145, pp. 383-391, 2017.

[56] N. Palankar, A. Shankar, and B. Mithun, "Durability studies on eco-friendly concrete mixes incorporating steel slag as coarse aggregates," J. Clean. Prod., vol. 129, pp. 437-448, 2016.

[57] D. Graffitti, "Evaluation of free lime content in steel slag (in portuguese)," M.S. thesis, Univ. Fed. Porto Alegre, Porto Alegre, 2002.

[58] J. Benezet and A. Benhassaine, "Grinding and pozzolanic reactivity of quartz powders," Powder Technol., vol. 105, no. 1-3, pp. 167171, 1999.

[59] E. Gutman, Mechanochemistry of Materials. Cambridge: Cambridge Int. Sci. Publ., 1998.

[60] Associação Brasileira de Normas Técnicas, Concrete for Structural Use: Density, Strength and Consistence Classification, ABNT NBR 8953, 2015.

[61] J. F. Lamond and J. H. Pielert, Significance of Tests and Properties of Concrete and Concrete-Making Materials. Bridgeport: ASTM International, 2006.

[62] E. Anastasiou, K. Filikas, and M. Stefanidou, "Utilization of fine recycled aggregates in concrete with fly ash and steel slag," Constr. Build. Mater, vol. 50, pp. 154-161, 2014.

[63] Y. Biskri, D. Achoura, N. Chelghoum, and M. Mouret, "Mechanical and durability characteristics of High Performance Concrete containing steel slag and crystalized slag as aggregates," Constr. Build. Mater., vol. 150, pp. 167-178, 2017.

[64] N. Roslan, M. Ismail, Z. Abdul-Majid, S. Ghoreishiamiri, and B. Muhammad, "Performance of steel slag and steel sludge in concrete," Constr. Build. Mater., vol. 104, pp. 16-24, 2016.

[65] Q. Wang and P. Yan, "Hydration properties of basic oxygen furnace steel slag," Constr. Build. Mater., vol. 24, no. 7, pp. 1134-1140, 2010.

[66] A. Brand and J. Roesler, "Interfacial transition zone of cement composites with steel furnace slag aggregates," Cement Concr. Compos., vol. 86, pp. 117-129, 2018. 
[67] J. Skibsted and R. Snellings, "Reactivity of supplementary cementitious materials (SCMs) in cement blends," Cement Concr. Res., vol. 124, pp. 105799, 2019.

[68] H. Reinhardt, "Factors affecting the tensile properties of concrete," in Understanding the Tensile Properties of Concrete, J. Weerheijm, Ed., Oxford: Woodhead Publ., 2013, pp. 19-51. http://dx.doi.org/10.1533/9780857097538.1.19.

[69] International Energy Agency Staff, Energy Technology Perspectives 2017: Catalysing Energy Technology Transformations. Paris: IEA, 2017.

[70] Fundação João Pinheiro, Déficit Habitacional no Brasil 2013-2014. Belo Horizonte: Cent. Estat. Inf., 2016.

Author contributions: LCBC: conceptualization, formal analysis, investigation, methodology, writing; MAN: methodology, writing. LCF: methodology, writing; FPFE: methodology, writing; JMFC: methodology, resources, supervision, writing; RAFP: supervision, resources, funding acquisition, writing.

Editors: Lia Pimentel, Guilherme Aris Parsekian. 